\title{
Diagnostics of the condition of marginal territories by lichen-indication methods
}

\author{
Aleksander Lugovskoy ${ }^{1,2, *}$, Aleksander Volgin $^{1}$, Petr Krylov $^{1}$, Mikhail Evdokimov ${ }^{1}$ \\ ${ }^{1}$ Moscow Region State University, 10A, Radio str., 105005, Moscow, Russia, \\ ${ }^{2}$ Moscow State University of Geodesy and Cartography, 4, Gorokhovsky Per., 105125, Moscow, \\ Russia
}

\begin{abstract}
The author's definition of marginal territories is based on the principle of their uniqueness, specificity, and isolation. Marginal territories mean closed border areas located on the edge of districts or isolated areas in the center under the influence of factors and released a higher diversity and number of species, characterized by isolation from the center, which are based on the isolation of life of the population of the district. The assessment of the quality of the environment for the comfort of living in marginal territories was carried out in comparison with the control areas related to the lands of localities and recreational territories. It is carried out on the basis of a comprehensive analysis of the habitat of groups of organisms sensitive to environmental degradation, belonging to the department of Lichens. The assessment of the condition of marginal territories was carried out by methods of determining the degree of lichen cover and the air pollution level parameter, the biotic index parameter, and the poleo-tolerance index in comparison with control territories related to the lands of settlements and recreational territories.
\end{abstract}

\section{Introduction}

The definition and classification of marginal territories is based on the principle of uniqueness, specificity, and isolation of districts and regions. Marginal territories mean closed areas located at the edge of countries and districts or in the center [29], but under the influence of any factors, more or less isolated areas and border territories, distinguished by a higher diversity and number of species and individuals localized here, characterized by a lack of organizations, isolation of the periphery from the center, the basis of which is the isolation of life, a large migration from the outskirts to the middle of the district [2-4]. As a result, we can say that marginal zones are located in the following territories: a - peripheral marginal lands; $\mathrm{b}$ - located in the middle of the second center and border territories; $\mathrm{c}$ marginal lands inside the country - partially isolated territories located around the fourth by the size, localities, but for some reason.

One of the main statistical indicators that allows speaking about the territory as marginal is the growth or decline in the number of residents outside the capitals of districts in comparison with the same growth or decline in residents inside the capitals of districts.

\footnotetext{
*Corresponding author: alug1961@yandex.ru
} 
M. V. Averina notes [5] that a marginal area is a marginal land with negative landscape conditions. The principle underlying the definition is differences in landscape conditions. The authors say that when describing specific urban areas, they most often use the concept of - "marginal" zone". This term originated in the depths of postmodernism. Based on the principle of national economic inexpediency of land use, Lipets Y.G. notes [6] that marginal lands are zones, the average harvest, that allows only to cover the costs of production, but it is not enough to pay rent [7]. Based on the principles of economic profitability, location of territories and various numbers of representatives, the paper "Agro Basket" gives the following definitions of the concept of marginal - 1) located on the edge; 2) closest to the limit, almost unprofitable; 3) represents a minority, as an example, marginal vegetation, marginal elements of society [8]. Based on the principles of vulnerability and specificity in the paper "Land resources in agriculture" [9], marginal territories are understood as erosional steep slopes, saline soils, land occupied by shrubs and other land in need of restoration measures - reclamation [12,19,35,39]. At the present moment, these territories are either not used, or production on them is not profitable [10]. This topic has been studied by a number of researchers, including foreign scientists [11]. Of European and American researchers this direction we note the following: Kostis Hadjimichalis (Greece), Judith Pallot, David Sadler, John Allen, Nick Henry, Chris Piquans, Kevin Rones, Mick Dunford, R. Hutson, R. J. Lewis, Dominic Moran (UK), Asu Aksoy (Turkey), Anthony Bailey (Switzerland), George Gaspar (Portugal), Christian Kesteloot (Belgium), Enzo Mingione, Enrica Pugliese (Italy), Jukka Oksa (Finland), Dina Vaios (Greece), Jan Van Wesep (Netherlands), V. Michalski (Poland), Erik Weiss-Altaner, L. I. Hamelin (Canada) [12-14].

In our country, the question of the ratio of outskirts and central regions is also raised. The domestic scientists in their writings show that currently, there is a decrease in the economic territory, the increasing confrontation of the central lands with marginal. A. P. Kutrovsky notes that the difference between central and marginal territories nowadays has significantly increased, as a result of polarization [15]. He notes that the difference between zones, including economic and social differences, is objective. The main task of local policy is to register assumptions very clearly and prevent possible differences between zones. E. N. Samburova [16] in her scientific work argues that the difference between the outskirts and the center is increasing. L. P. Bogdanova and A. S. Shchukina in their works [17] described the differences between the middle and the outskirts of the Moscow region. One of the priorities of this zone is its proximity to economically developed regions and the ability to unite a strong market around itself [18]. At the end of the 20th century, the decline in social factors in the Moscow region was much faster than in other regions [19]. The increase in marginality is highlighted by internal regional transport accessibility. Territories with low transport accessibility are usually outskirts, and transit-type areas also have marginal factors [21].

Marginal land - a zone that touches two different cultures and affects them. Authors considers the agricultural land based on the principle of differences in the suitability of their use. Rosi Philip Kapleau [22] under marginal land understands, land not suitable for sowing, but used for grazing the cattle. Many researchers recognize that despite the fact that cattle grazing is performed on marginal lands, it can still cause harm to these territories. It is noted that marginal lands are territories that are unsatisfactory for agriculture, or simply abandoned, and this concept is based on the principle of suitability for agriculture. Based on the principle of low quality of agricultural land, the marginal zone is a zone of integrated cattle farming. Marginal territories are considered as transitional territory in mountainous and foothill areas with unsuitable land for agriculture, with a lack of oxygen, low night temperatures, freezing soil, requiring constant moisture, with low fertility, the concept is based on the principle of uniqueness and specificity of territories. 
The principle that is the basis for defining marginal territories is the poor quality of agricultural land. Under marginal lands Kukolschikova S. B. [23] understand territories used only for pasture cattle breeding and not suitable for agriculture. According to the authors, these regions have the opportunity to use them for the production of annual and perennial forage grasses, as well as in these areas, the economy can switch to local mass resources in the form of collecting and harvesting mushrooms and berries. Now more and more rural land is being put out of use. This is due to the destruction of the soil layer, overgrowth of fields with shrubs and trees, and land alienation. Therefore, the lack of rural land is compensated by the development of marginal land of low fertility and low quality. The definition is based on the principles of economic feasibility and the difference in climatic conditions. Lipets Y. G. [24] under marginal lands understands - 1) the cost of land cultivation pays off, but they do not bring profit; 2) where the balance between heat and moisture is very fragile, and easily disturbed. V.P. Maksakovsky [25] notes that the marginal zone is territories with low fertility, located on the border territory between humid and arid areas, which leads to a decrease in yields. The principle underlying the concept is the difference between humidity of the territories.

The term "marginal area" originated in the depths of postmodernism and meant marginal land with negative landscape conditions, based on the principle of accounting for differences in landscape conditions. When describing specific urban areas, the term "marginal" zone" is most often used.

From a geographical point of view, the outskirts are of least interest to economic geographers. The old theories explain mainly the territorial causes of the main countries and areas -this is the theory of the main places, the concept of a set of interconnected industries located next to each other, and the set of production processes deployed in the region, based on available raw materials and energy. The difficulties of the periphery are not analyzed here and are ignored. During the USSR period, the outskirts of districts moved in parallel with their central territories at the level that was under planned farming. Along with efficient industries in remote areas, the State created a sphere of unprofitable, but popular enterprises for residents, distributing the load of marginal lands to the whole region. With the transition to market relations, all the advantages and disadvantages of the impact of distance from growth points and district centers have become clearly visible. Closed territories, called marginal in the literature, are a new feature for our country, which is moving to market relations. These areas are located on the remote border territory of countries or districts. Marginal territories can be divided according to the level of relief diversity: a uniform relief margin throughout the district and a diverse relief margin on those lands where the natural boundaries of opposites are located. The outskirt is also divided by accessibility for transport: - the outskirt through which major inter-district transport arteries pass; - outskirts that are far from major highways.

The basis for defining marginal territories is the configuration of regions. When we correlate the volume of regional cities with the distance to the center of the region in accordance with spatial schemes, the following model appears. The capital will be located in the center, at a great distance from the capital will be located, the second by volume largest cities, third localities will be satellites of the capital, and in the middle between the second and third will be marginal localities.

In any tier, researchers mark the central part and edges. These terms are subjective, since the same zones are considered from different sides, due to the scope of the study. The term "marginal land" is not synonymous with the concept of depressed areas, despite a large number of similar features. Marginal lands have the potential for growth, but due to the situation of these lands, they cannot find development resources at this time. The concept of "marginal" is relatively short-lived in earth science. The term has various interpretations in geography: extreme lands that directly border the center; geographically 
located nearby; related to the border or are part of the district. In economics the concept is used with the following meanings: - only covering the lower acceptable level; - the manufacturer's company that only covers its expenses and no profit; - everything that opposes the new, developed; - bordering on something.

As a result, marginal territories in the system of geographical sciences are understood as underdeveloped, sparsely populated, remote from the center, wild, borderland.

\section{Materials and methods of the research}

To perform research work in the field, we used standard methods that are repeatedly described in the literature [26-28]. Determination of the degree of lichen cover of trees was performed using a pallet made of thick polyethylene, the size of which is $20 \times 20 \mathrm{~cm}$.

In the field, the analysis of the city street and the territory in the zone of influence of enterprises: is made according to the following criteria: side of the street (sunny, shadow); type of vehicles; presence of high-rise buildings; presence of air purges between buildings; increase or decrease of air purging at intersections; parking of buses, vehicles; proximity of green spaces to the road; type of plantings (protective plantings; natural plantings; abandoned territory); stable and unstable types of tree stands. When analyzing plants, we were able to: phenological phase; leaf chlorosis; the presence of dead tissue in the form of necrosis (point, edge, interstitial, radial); the presence of leaf pigmentation; damage by pests and diseases, the degree and nature of it. After conducting the study, it's necessary to draw conclusions about the most stable types of trees, and to justify the causes of plant damage.

Data was collected from 10 trees without damage and of the same age and type. A pallet is applied to the trunk at a height of 0.3-1.3 m and the sum of squares filled with lichens, the number of their species, as well as the number of lichens of the dominant species is calculated.

The results were processed using three methods. First method: first determine the arithmetic mean degree of lichen coverage of tree trunks; the resulting value is compared with the values of the air quality scale and make a conclusion about the parameter of the degree of air pollution.

The second method is to give an exact name to all found lichens using lichen determinants, and then, using a working scale, determine the biotic index parameter that will characterize the degree of pollution.

The third method: first we define the class of poleo-tolerance, using all the found lichen species; then we calculate the parameter of the poleo- tolerance index (1) using the formula:

$$
I P=\sum_{i=1}^{n} \frac{K m_{i} * P n_{i}}{P n},
$$

where $P n$ - projective cover of common, $K m_{i}$ - class of tolerance in type $1, \mathrm{Pn}_{i}-1$ the projective cover of 1 type; at the last step we calculated the average index of poleotolerance for all ten trees and compare the resulting value with the data from the calibration table "Index of poleo-tolerance and annual average $\mathrm{SO}_{2}$ ", which allows to determine the degree of air pollution.

The territorial location of the study polygons where the physical, geographical and environmental parameters were evaluated according to the standard plan [29] within the marginal zones of Moscow is shown in figure 1. 


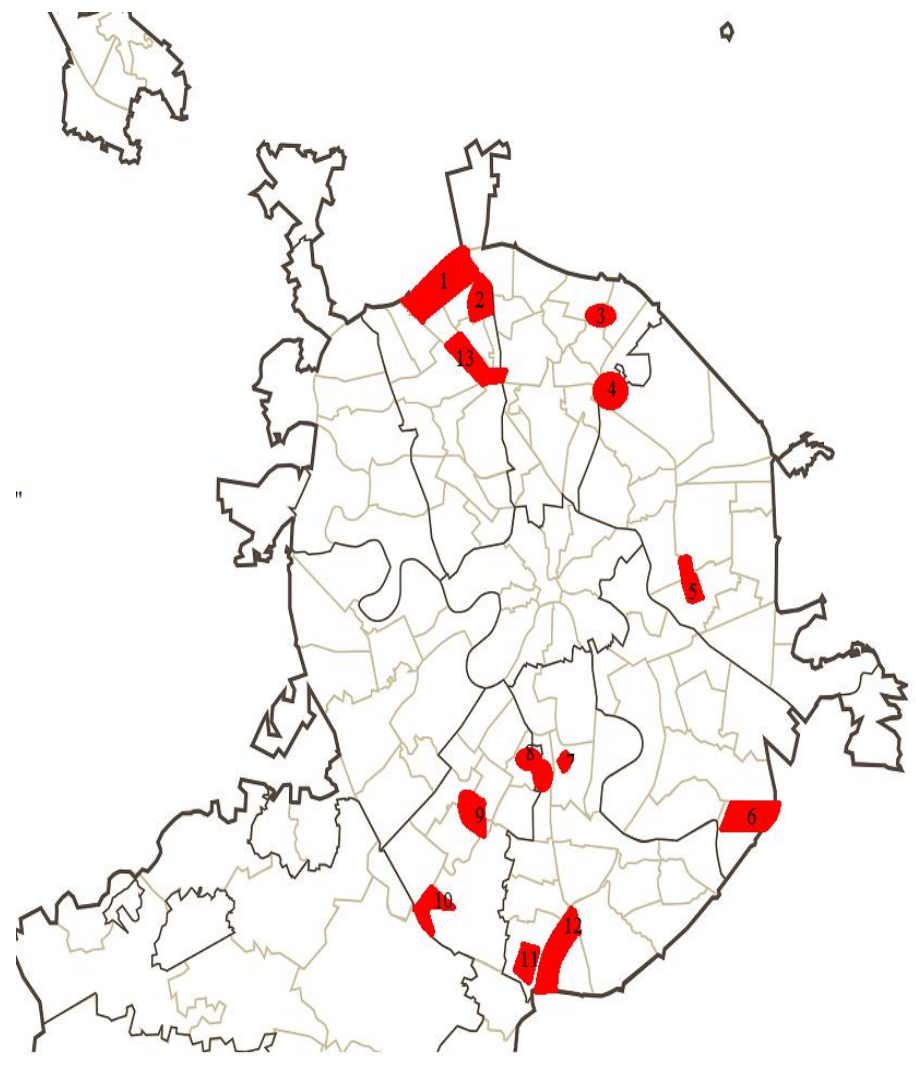

Figure 1. Mapping of the study polygons.

Convention: 1.- "Korovino" industrial zone, 2. - "Vagonoremontnaya" industrial zone, 3. "Ostashkovskoe shosse" industrial zone, 4. - "Severyanin" industrial zone, 5. "Prozhektor" industrial zone, 6. - "Kapotnya" industrial zone, 7. - "Nagatino" industrial zone, 8. - "Verkhnie kotly" industrial zone, 9. - "Vorontsovo" industrial zone, 10. - "Teply stan" industrial zone, 11. - industrial zone "Krasny stroitel", 12. - "Biryulyovo" industrial zone, 13. - "Degunino-Likhobory" industrial zone.

\section{Results and discussion of the research}

As a result of processing the results of measuring the parameters of indicators of the degree of pollution, the biotic index and the poleo-tolerance index, a table was compiled 1 .

Table 1. Characteristics of the condition of marginal zones and control territories.

\begin{tabular}{|c|c|c|c|c|c|c|c|}
\hline No & $\begin{array}{c}\text { Marginal and } \\
\text { control } \\
\text { territories }\end{array}$ & $\begin{array}{c}\text { Tegree } \\
\text { of } \\
\text { coverage } \\
\text { of the } \\
\text { lichen, } \\
\text { \% }\end{array}$ & $\begin{array}{c}\text { Number } \\
\text { of } \\
\text { species }\end{array}$ & $\begin{array}{c}\text { Number of } \\
\text { lichens of } \\
\text { the } \\
\text { dominant } \\
\text { species }\end{array}$ & $\begin{array}{c}\text { Pollution } \\
\text { level }\end{array}$ & $\begin{array}{c}\text { Biotic } \\
\text { index }\end{array}$ & $\begin{array}{c}\text { The } \\
\text { index of } \\
\text { paleo- } \\
\text { tolerance }\end{array}$ \\
\hline 1 & $\begin{array}{c}\text { "Korovino" } \\
\text { industrial zone }\end{array}$ & 29 & 2 & 18 & 4 & 7 & 8 \\
\hline 2 & "Teply stan" & 57 & 2 & 52 & 4 & 8 & 6.59 \\
\hline
\end{tabular}




\begin{tabular}{|c|c|c|c|c|c|c|c|}
\hline & industrial zone & & & & & & \\
\hline 3 & $\begin{array}{c}\text { "Bitsevsky forest } \\
\text { park" } \\
\text { Control }\end{array}$ & 12 & 1 & 9 & 2 & 6 & 4.2 \\
\hline 4 & $\begin{array}{c}\text { "Biryulyovo" } \\
\text { industrial zone }\end{array}$ & 12 & 2 & 8 & 2 & 6 & 8.58 \\
\hline 5 & $\begin{array}{c}\text { "Bitsevsky forest } \\
\text { park" } \\
\text { Control }\end{array}$ & 60 & 3 & 39 & 5 & 5 & 4 \\
\hline 6 & $\begin{array}{l}\text { "Prozhektor" } \\
\text { industrial zone }\end{array}$ & 23 & 1 & 26 & 4 & 7 & 6 \\
\hline 7 & $\begin{array}{l}\text { "Izmailovsky } \\
\text { forest park" } \\
\text { Control }\end{array}$ & 51 & 2 & 49 & 5 & 8 & 6.08 \\
\hline 8 & $\begin{array}{c}\text { "Kapotnya" } \\
\text { industrial zone }\end{array}$ & 28 & 2 & 13 & 4 & 8 & 6.06 \\
\hline 9 & $\begin{array}{c}\text { "Kuzminki" } \\
\text { Control }\end{array}$ & 44 & 2 & 17 & 4 & 7 & 8.44 \\
\hline 10 & $\begin{array}{l}\text { "Vagonoremont" } \\
\text { industrial zone }\end{array}$ & 19 & 3 & 23 & 2 & 8 & 6.15 \\
\hline 11 & $\begin{array}{l}\text { "Ostashkovskoe } \\
\text { shosse" industrial } \\
\text { zone }\end{array}$ & 41 & 1 & 45 & 4 & 7 & 7 \\
\hline 12 & $\begin{array}{c}\text { "Losiny Ostrov" } \\
\text { Control }\end{array}$ & 23.7 & 1 & 41 & 4 & 8 & 6 \\
\hline 13 & $\begin{array}{l}\text { "Verkhnie kotly" } \\
\text { industrial zone }\end{array}$ & 24 & 1 & 4 & 3 & 4 & 7 \\
\hline 14 & $\begin{array}{c}\text { "Nagatino" } \\
\text { industrial zone }\end{array}$ & 34 & 2 & 30 & 4 & 8 & 6.65 \\
\hline 15 & $\begin{array}{l}\text { "Vorontsovo" } \\
\text { industrial zone }\end{array}$ & 57 & 2 & 52 & 4 & 8 & 6.59 \\
\hline 16 & $\begin{array}{c}\text { "Bitsevsky forest } \\
\text { park" } \\
\text { Control }\end{array}$ & 70 & 3 & 60 & 5 & 5 & 4.9 \\
\hline 17 & $\begin{array}{c}\text { "Degunino- } \\
\text { Likhobory" } \\
\text { industrial zone }\end{array}$ & 22.1 & 1 & 41.6 & 4 & 7 & 6 \\
\hline 18 & $\begin{array}{l}\text { "Severyanin" } \\
\text { industrial zone }\end{array}$ & 35 & 2 & 33 & 3 & 8 & 7 \\
\hline 19 & $\begin{array}{c}\text { "Losiny Ostrov" } \\
\text { Control }\end{array}$ & 45 & 2 & 101 & 4 & 8 & 6.28 \\
\hline 20 & $\begin{array}{c}\text { "Krasny } \\
\text { stroitel" industrial } \\
\text { zone }\end{array}$ & 40 & 3 & 46 & 4 & 8 & 6 \\
\hline 21 & $\begin{array}{c}\text { "Bitsevsky forest } \\
\text { park" } \\
\text { Control }\end{array}$ & 60 & 3 & 39 & 5 & 5 & 4 \\
\hline
\end{tabular}

Note: degree of pollution: 2-strong pollution; 3-moderate pollution; 4-relatively clean air; 5-clean air. Biotic index: 7-8-clean air; 5-6-relatively clean air; 4-moderate air pollution. Poleo-tolerance index: 1-2 - very clean air; 2-5.5-clean air; 5.6 - 7.5 relatively clean air; 7.6 - 9.5-moderate pollution; 9.6 or more-highly polluted air.

The analysis of environmental parameters allows us to assert the possibility of using all three indicators together or in different variations to improve the accuracy of environmental quality assessment and data verification for a comprehensive analysis of the environmental situation. 
The results obtained allowed us to evaluate the condition of the environment with a high degree of accuracy in comparison with the control. This makes it possible to assume that a person can live comfortably in these territories. The data obtained were rechecked in the control territories, which, as a rule, do not have a high negative impact from anthropogenic activities.

The discrepancy in the indicators indicates the influence of an additional factor that requires identification and further research (figure 2). The parameters for assessing the condition of atmospheric air by lichen-indication method using the poleo-tolerance index are indicated by measurements in control territories, and marginal territories with research polygons are indicated in red.

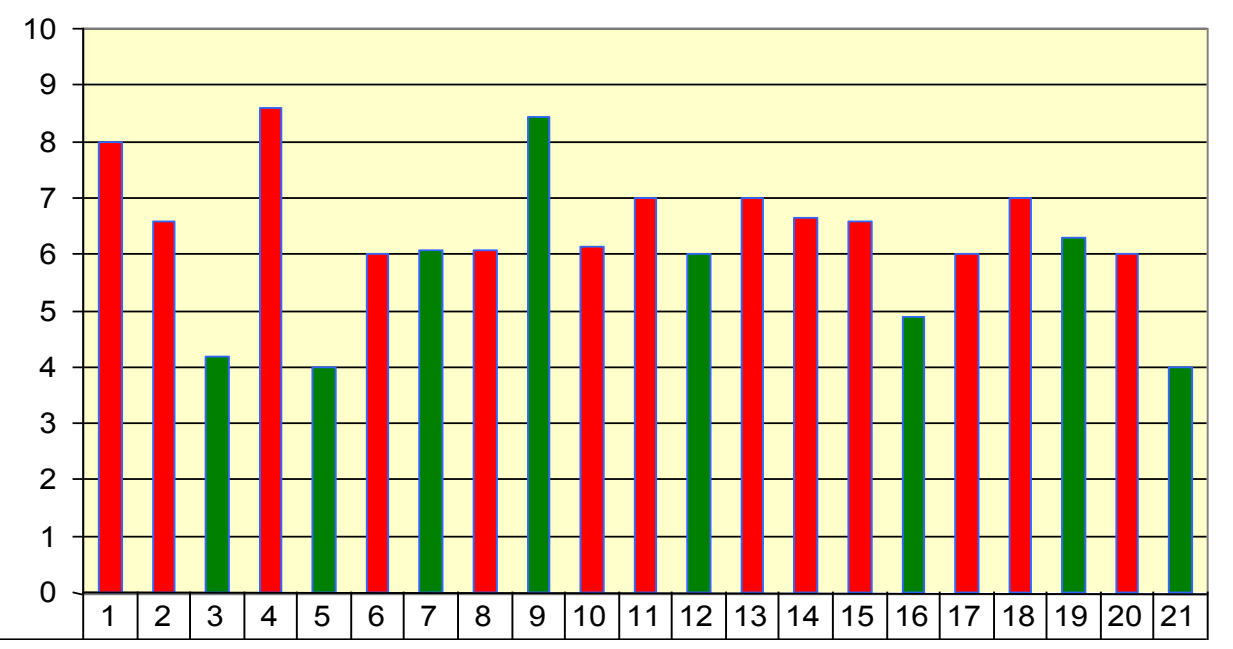

Fig. 2. Parameters for assessing the condition of atmospheric air by lichen-indication method using the poleo-tolerance index: 1-2 - very clean air; $2-5.5$-clean air; $5.6-7.5$ relatively clean air; 7.6 9.5-moderate pollution; 9.6 or more-heavily polluted air, 1-21-numbers of marginal and control areas.

In our opinion, the purity of atmospheric air is an integral indicator that characterizes the degree of pressure on the environment from the main dominating components-industrial production and transport. Air purity as an integral indicator is high in areas suitable for permanent residence and recreational activities. The strategy of including marginal territories in social and economic turnover is primarily related to increasing their comfort for long-term use by citizens. We do not reject another way of using marginal territories in terms of their further isolation, with a tougher regime for using as polygons for storing the products of civilization's activities until the time when technologies for their utilization will be offered. However, this way is not acceptable in large cities, where the cost of land is very high, and the requirements for the efficiency of their use is the most important function of the city.

If marginal zones reduce their productivity and the quality of the environment is critical, then people living in these territories will most likely have to leave them and move to other parts of the city, where the infrastructure has reached its maximum due to the territorial load of the population.

\section{Conclusion}

The assessment of the quality (comfort) of the environment for the living of population in marginal territories was carried out in comparison with the control territories related to the lands of localities and recreational territories. It is carried out on the basis of a 
comprehensive index of poleo-tolerance, reflecting the comfort of living groups of organisms sensitive to environmental degradation related to the department of Lichens. This indicator is sensitive to changing the parameters of the degree of projective lichen cover, reducing the number of species while reducing the number of dominant species. We used a comparison of the effectiveness of three methods of coupled assessment of the degree of pollution, the biotic index and the poleo-tolerance index. This allowed us to apply the scientific principle of verification of the results of a comprehensive assessment to justify the proposal to involve marginal territories within the urban geo-systems of the megalopolis in social and economic turnover.

\section{References}

1. Marginal lands, Dictionaries and encyclopedias on Akademik (1997) http://big_economic_dictionary.academic.ru/4903

2. Large encyclopedic dictionary, http://enc-dic.com/enc_big/Marginalnyj-35044.html

3. Glossary.ru, http://www.glossary.ru/cgi-bin/gl_sch2. cgi?R1dMgwmg

4. G.A. Bortnikova, A.M. Lugovskoy, L.A. Mezhova, Advances in modern natural science 12, 139 (2016)

5. M.V. Averina, The concept of marginality as a tool for analyzing social and cultural dynamics. thesis: 24.00 .01 (2015)

6. Y.G. Lipets, Geography of the world economy: textbook (Moscow, Vlados, 1999)

7. A.P. Kutrovsky, Territorial justice, regional conflicts and regional security: materials of scientific conference (Smolensk, SSU Publishing house, 1998)

8. Agro Basket: Dictionary box (2012) http://agrocart.com/2521/slovarnaya-shkatulka

9. Land resources in agriculture (2012) http://student.zoomru.ru/ekonom/zemelnyeresursy-v-selskom-hozyajstve/81792.666034.s1.html

10. Y.V. Lyadkina, A.M. Lugovskoy, Advances in modern natural science 10, 135 (2016)

11. Effective management of marginal lands to improve the winter feed production system and diversify rural incomes, http://cac-program.org/ru/news/detail/479

12. V. Holodkova, A. Mottaeva, T. Pokrovskaya, E3S Web of Conferences 164, 11043 (2020) https://doi.org/10.1051/e3sconf /202016411043

13. A.I. Zyryanov, Marginal territories of 2008, Geographical Bulletin 2 (2008)

14. A.I. Zyryanov, Region: Spatial relations of nature and society. dissertation of candidate of geography science: 25.00 .24

15. E.N. Samburova, Territorial justice, regional conflicts and regional security: materials of scientific conference (Smolensk, SSU Publishing house, 1998)

16. L.P. Bogdanova, A.S. Shchukina, Territorial justice, regional conflicts and regional security: materials of scientific conference (Smolensk, SSU Publishing house, 1998)

17. N.V. Zubarevich, Types of regions of Russia by the level of social and economic development. Dissertation of Doctor of geography sciences (Moscow, 2003)

18. V. Kagansky, Russian magazine (2004) http://old.russ.ru/culture/20040913_kag.html 
19. N.P. Burova, Center-periphery: territorial inequalities and territorial justice. Social and economic status areas of Verkhopen'ye

20. V.S. Gorbunov, L.A. Mezhova, A.M. Lugovskoy, V.T. Dmitrieva, G.M. Mainasheva, Advances in modern natural science 11, 111 (2016)

21. R.F. Kapleau, Cherish all life (Moscow-SPb., "Karma Yeshe Paldron", 2001) http://www.theosophy.ru/lib/budd-veg.htm

22. S.B. Kukolschikova, Agriculture as a source of chemical pollution of the Biosphere (Moscow, 2000)

23. L. Shabalina, L. Kopteva, A. Mottaeva, E3S Web of Conferences 175, 13040 (2020) https://doi.org/10.1051/e3sconf/202017513040

24. D.P. Maksakovsky, Geography 10 class (Moscow: "Prosveshchenie" publishing house, 2008)

25. V.N. Lavrova, A.G. Muravjev, N.A. Pugal, Ecological workshop. Textbook (Saint Petersburg, Crismas + , 2003)

26. G.N. Lopatina, Ecology and Economics of nature management: textbook for universities (Moscow, Unity-Dana, 1998)

27. A.N. Nikolskaya, A.I. Fedorova, Practicum on ecology and environmental protection (Moscow, Vlados, 2001)

28. Plan of physical and geographical characteristics, Ecological-social project "Small motherland", http://www.unnat.ru/eco/geo.htm 